\title{
ADOPTION OF EDUCATIONAL TECHNOLOGY: STUDY ON HIGHER EDUCATION
}

\author{
Garaika, Helisia Margahana \\ Lecture, Department of Management, \\ Sekolah Tinggi Ilmu Ekonomi Trisna Negara Sumatera Selatan, Indonesia
}

\begin{abstract}
This study aims to examine the adoption of innovation technology (e-learning) in universities in Indonesia, by emphasizing individual internal factors that influence adoption. The internal factors analyzed in this study are user motivation, perceived ease of use, trust and personal innovativeness. This research is a type of survey research with the respondents being lecturers at the University. This study used a questionnaire to obtain data, and data were analyzed using structural equation modeling (SEM). The results of data analysis indicate that not all proposed hypotheses are accepted. There is one hypothesis that is not supported, namely the hypothesis of the influence of personal innovativeness on e-learning adoption. The influence of motivation on e-learning adoption, and trust in e-learning adoption is supported. Likewise, the effect of perceive ease of use on trust is also supported.
\end{abstract}

Keywords: adoption, motivation, ease of use, trust and innovativeness.

Cite this Article: Garaika, Helisia Margahana, Adoption of Educational Technology: Study on Higher Education, International Journal of Management (IJM), 11 (1), 2020, pp. 61-71.

http://iaeme.com/Home/issue/IJM?Volume=11\&Issue=1

\section{INTRODUCTION}

The education sector is a field that has benefited a lot from information technology. Countries that tend to succeed in education have information technology in the field of education that is also strong (Lekopanye and Mogwe, 2014). Many countries around the World, do everything possible to handle the challenges of technology adoption in the field of education, through increasing skills, introducing technology and providing training to educators at all levels.

For universities, e learning technology in the field of teaching and learning becomes a matter that needs attention. Many universities are increasingly prioritizing e-learning adoption (Selander, 2008). The adoption of e-learning in teaching in higher education is the main focus of researchers in education and human resources. This delay in adoption has become mainstream and concerns are growing among universities (Selwyn, 2013).

Investing in technology at a university must be a top priority, because of the demands of competition and an increasingly familiar student population with digital (Sabelli and Harris, 
2015). (Sabelli and Harris, 2015) state that research on the adoption of innovations in the field of education is interesting to do despite the many challenges facing researchers. Rogers et al., (2005) state that the diffusion of sustainable innovation is achieved when critical mass has passed, meaning that there are enough adopters who become independent.

Most e-learning innovations originating from the practice of teaching higher education fail to reach this critical mass point (Markus (1987). Pacansky-Brock (2015) illustrates that elearning innovation innovation fails to be adopted by academics in teaching at universities. Many universities facing the era of internet revolution on campus which is faster than anticipated.The use of computer technology and the Internet has aroused interest, as well as resistance and opposition to the use of information technology in university education (Abrahams, 2010). There are two: (1) the first attitude shows that the use of technology in education does not cause significant learning differences. (2) On the other hand claims that technology in higher education makes academic information more accessible, more affordable, and more effective.

The report entitled "Indonesia digital education and e-Learning Market Outlook to 2018 Rising Trend of Blended to Drive the Future Growth" describing total expenditure on digital education in Indonesia has grown in the last five years (https://www.liputan6.com/ tekno / read / 3226423 / e-learning-increasingly-attention-in-2018). The report also shows that there is increasing collaboration between educational institutions and digital education providers to complement their classes with digital education facilities. The leading well-known educational institutions in the country have become more receptive to the application of Hitech learning components. Technological advancements in the field of education in Indonesia have provided a number of benefits for educational institutions as well as corporate trainers such as multi-capital training, online tests and tutorials, live video streaming with teaching faculties and several other facilities. The diffusion of e-learning innovations in higher education is carried out in teaching practice. Through this diffusion of e-learning innovations, academics at the university adopt new ways of learning and teaching using digital technology.

This study aims to examine the acceptance of innovation technology adoption in universities in Indonesia, by analyzing individual internal factors that influence adoption. The internal factors analyzed in this study are user motivation, perceived ease of use, trust and personal innovativeness. Research on the adoption of technological innovations in higher education is important because according to Abrahams, (2010) many universities do not understand why some technological innovations have been adopted successfully, and other technologies have failed to be adopted. Higher education institutions that are able to manage the adoption process and / or diffusion of innovation earlier, are more likely to innovate more effectively. Universities need to identify and manage the diffusion of innovations, whether there is a rejection or acceptance of the implementation of technology on campus by using the theory of diffusion of innovation.

\section{LITERATURE REVIEW}

\subsection{Adoption of Technology on Higher Education}

The definition of innovation has been explored from various perspectives and disciplines, such as business management, sociology, anthropology and psychology. The problem that often arises when first reviewing innovation is the problem of how innovation is defined. There is a tendency for researchers to give relatively different definition editors. This study uses the definition of innovation proposed by Rogers and Shoemaker (1971) and Rogers (2003). Roger and Shoemaker (1971) define innovation as new ideas, new practices, or objects that can be felt as something new by the individual or target community. The new definition here, contains meaning not only just known by the mind, but also new because it 
has not been widely accepted by the whole community in terms of attitude and also new in the sense that it has not been accepted and applied by all residents of the local community.

For some innovations, actually the potential target of users is divided into two, adopters (adopters) and not adopters (non adopters) of new technologies. Adopters are classified into 5 (five) namely: innovators, early adopters, early majority groups, late adopters, and late adopters. This classification has become the standard for positioning adopters in the decades to decades now. This classification is a temporal construct based on the length of time the adopter has passed before adopting a technological innovation. Each of these categories has different levels of resistance and time of adoption (Rogers, 2003).

Related to technology adoption in universities, web-based teaching technology and elearning tend to be seen as innovative projects. In this domain, Rogers' theory emerges as a framework for understanding the diffusion process of innovation (Sahin \& Thompson, 2006). The process of innovation decision is the process through which individuals begin from first knowing the existence of innovation, then proceeding with an agreed decision on innovation, determining the decision to accept or reject innovation, implement innovation, and confirm the innovation decisions that have been taken (Alone, 2017). The process of innovation decision is not an activity that can take place instantly, but is a series of activities that take place within a certain period of time, so that individuals or organizations can assess the new idea as a consideration to subsequently reject or accept innovation and apply it. The main feature of innovation decisions and their differences from other types of decisions is that they begin with uncertainty about something. According to Roger, the innovation decision process consists of 5 stages, namely the knowledge stage, the stage of persuasion, the decision stage, the implementation stage and the confirmation stage (Rogers, 2003).

E-Learning technology is a technology based on information technology infrastructure. For this reason, the adoption model of Information and Communication Technology is useful in explaining the adoption of E-Learning Technology. A number of models that explain and predict user behavior and intentions to adopt technology are proposed by Davis (1989) \& revised TAM Model by Lee et al., (2013). Technology acceptance model (TAM) proposes two factors to predict the use of technology, namely perceived usefulness and perceived ease of use (Davis, 1989). In TAM Perceived usefulness (PU) is conceptualized as the rate at which users believe that using certain innovations will improve their performance. Perception of ease of use (PEOU) is the extent to which users believe that using innovation will be free from physical and mental effort (Davis, 1989). Lee et al., (2013) in the revision of the TAM model, suggested that, the five attributes of innovation (compatibility, complexity, relative advantage, ability to try and observability) have important effects on perceived benefits, perceived ease and intention to adopt e-technology learning.

\subsection{Motivation and Adoption e-learning}

This research uses expectancy theory to explain the motivation to adopt e-Learning technology. According to Vroom (1964), expectation theory consists of two related models, namely the valence model and the force model. The valence model describes the attraction that is felt to achieve the main results. The force model uses the power of motivation to influence someone to act to adjust valence of the outcome (Campbell et al., 2003). According to Chen et al., (2012), adoption of e-Learning technology tends to be more successful when technology is perceived to be the best interest and when the technology can produce successful adoption with reasonable efforts. Previous research (DeSanctis, 1983) shows that the expectancy theory approach can improve user understanding regarding adoption attitudes and behaviors. Chen et al., (2012), conducted a study on the application of expectation theory by measuring user attitudes towards technology eLearning and motivation to adopt e-learning 
technology. The results of his research show that by basing on expectancy theory, Chen et al. (2012) provides a better understanding that motivation can accurately predict the adoption of e-Learning technology. Motivation for information acquisition can direct efforts to adopt technology. User preferences and motivation must be seriously considered when technology is implemented.

\section{H1: Motivation influences e-learning adoption}

\subsection{Perception of Ease of use and Trust}

Technology Acceptance Model (Davis, 1989) considers that two individual beliefs, namely perceived usefulness and perceived ease of use have a major influence on the behavior of technology acceptance. The Technology Acceptance Model is actually adopted from the Theory of Reasoned Action (TRA) model, which is a theory of reasoned actions developed by Fishben and Ajzen (1975), with one premise that a person's reactions and perceptions of things determine people's attitudes and behavior that is. Ease of use (EOU) means without difficulty or freed from difficulties. Thus the perception of the ease of using this refers to the individual belief that the adoption of technology that will be used is not troublesome or does not require large effort when used. Perceptions of benefits and perceptions of ease of use influence individual attitudes, which in turn will determine whether people intend to adopt technology (Sugandini et al., 2016). The adoption of this technology involves the assessment of individuals on their involvement in using technology (Lee et al., 2013). The results of Chinomona's (2013) study stated that the ease of using technology is a predictor or antecedent of trust (emotional and social aspects) and intention to use technology. The reason is that the more users easily use new technology, the more likely they are to trust technology and consequently their intention to use it will also increase. Johnson, Levine, Smith \& Stone, (2010) also prove that there is a link between ease of use, trust and adoption of new technologies.

H2: Perception of ease of use has an effect on trust

\subsection{Trust and Adoption of e-learning Technology}

Trust is an important component in adopting innovation. Trust will increase attention to information (Sugandini et al., 2016). Trust in technology according to Discroll (1978) is divided into two dimensions: (1) trust in measuring the current situation (2) trust as a person or someone's tendency. When trust is tested as a person-carrying variable, individuals with low levels of trust generally avoid risk compared to individuals with high levels of trust. From the perspective of diffusion of innovation, Weber and Hsee (1998) and Joseph (2005) state that trust is related to the truth of the source of information that I receive about new innovations. Chinomona (2013) states that trust is an antecedent variable in predicting technology adoption. Trust is defined as the belief that technology will function in accordance with user expectations (Gefen \& Straub, 2004). Therefore, it is assumed that the more users trust technology to carry out their activities, the more users tend to use it. Previous research also supports a positive relationship between trust and technology adoption (Au \& Kauffman, 2008; Schierz et al., 2010, Sugandini et al., 2018a).

H3: Trust influences the adoption of e-learning technology.

\subsection{Personal Innovativeness and Adoption of e-learning Technology}

Personal innovativeness is the intrinsic factor most often used in predicting innovation adoption (Migley and Dowling, 1978). Innovativeness is defined by Rogers and Shoemaker, (1971) as an individual's speed rating in adopting innovation compared to other system members. Another definition states that innovativeness is the degree to which an individual 
takes innovation decisions freely or without the influence of others and does not decide on adoption of innovation based on communication experience (Midgley, 1977). Individuals who have very high levels of innovation have very strong intrinsic motivation to adopt new technologies (Nov, Ye 2008). The results of the study show that the successful implementation of a technology system also depends on personal innovativeness ( $\mathrm{Lu}$ et al., 2003, 2005; Rogers et al., 2005). Innovativeness plays an important role in determining the use of new technology (Yi et al., 2006). In this study, innovativeness is considered as an antecedent of the process of receiving e-learning technology.

H4: Personal Innovation influences the adoption of e-learning

\section{METHODOLOGY}

The study was conducted in the form of a survey, using an explanatory research approach, namely research that explains the causal relationship between variables through testing hypotheses (Sekaran, 2003), as well as with sample surveys namely samples taken from a population and using questionnaires as the main data collection tools and individual analysis units (Sugandini et al., 2018b). The population in this study were all lecturers in the South Sumatra region, Indonesia who had adopted e-learning. Convinience sampling is used as a sampling technique, because there are no certain restrictions on the sample taken. The sample range in this study includes all lecturers who have adopted e-learning in learning to their students, regardless of the length of time they are lecturers, the origin of their education, gender and age during the data collection period. The number of samples in this study was 225. Five extracts were measured using 5 Lickert scale points. The data analysis technique uses SEM with the AMOS (Analysis of Moment Structure) program. Direct influence (path coefficient) is observed from standardized regression weights, by testing the comparative significance of the CR (Critical Ratio) value which is equal to the value of $t$ count. From the output of the AMOS program a causal relationship between variables will be observed by looking at the direct effects and indirect effects and their total effects. Assessment of significance is based on the probability value (p), the significance limit used is the $p$ value of $\leq 0.05$. Tests on models developed with various Goodness of Fit criteria, namely Chi-square, probality, RMSEA, GFI, and TLI (Hair et al., 1998).

\section{RESULTS AND DISCUSSION}

Characteristics of respondents in this study consisted of: $60 \%$ men and $40 \%$ women. The education level for S2 is $85 \%$ and S3 is $15 \%$. Age of respondents ranged from 40 to 60 years. Length of work 5-25 years. The results of testing validity and reliability using confirmatory factor analysis. 0.4 and are reliable. $\geq$ The results show that five constructs: motivation, PEOU, trust, personal innovativeness and adoption of e-learning consisting of 19 questions are stated to be of good validity because they have standardized factor loadings Reliability in this study is indicated by the value of construct reliability above 0.70 and recommended extracted variance greater than 0.50 (Hair et al., 1998). The results of testing validity and reliability can be seen in table 1 .

Table 1. Validity and Reliability Test Results

\begin{tabular}{|c|c|c|c|c|c|}
\hline & $\begin{array}{c}\text { Standardize Factor } \\
\text { Loading }\end{array}$ & Validity & $\begin{array}{c}\text { Construct } \\
\text { Reliability }\end{array}$ & $\begin{array}{c}\text { Variance } \\
\text { Extrated }\end{array}$ & Reliability \\
\hline M1 & 0.78 & Valid & & & \\
\hline M2 & 0.667 & Valid & & & \\
\hline M3 & 0.871 & Valid & & & \\
\hline Motivation & & & 0.942 & 0.847 & Reliable \\
\hline
\end{tabular}




\begin{tabular}{|c|c|c|c|c|c|}
\hline$T 1$ & 0.519 & Valid & & & \\
\hline$T 2$ & 0.513 & Valid & & & \\
\hline$T 3$ & 0.516 & Valid & & & \\
\hline$T 4$ & 0.657 & Valid & & & \\
\hline Trust & & & 0.954 & 0.838 & Reliable \\
\hline PEOU1 & 0.836 & Valid & & & \\
\hline PEOU2 & 0.793 & Valid & & & \\
\hline PEOU3 & 0.768 & Valid & & & \\
\hline PEOU4 & 0.528 & Valid & & & \\
\hline PEOU5 & 0.679 & Valid & & & \\
\hline $\begin{array}{c}\text { Perceived ese of } \\
\text { use }\end{array}$ & & & 0.956 & 0.581 & Reliable \\
\hline AEL1 & 0.606 & Valid & & & \\
\hline AEL2 & 0.531 & Valid & & & \\
\hline AEL3 & 0.701 & Valid & & & \\
\hline $\begin{array}{l}\text { e-Learning } \\
\text { Adoption }\end{array}$ & & & 0.898 & 0.522 & Reliable \\
\hline PI4 & 0.467 & Valid & & & \\
\hline PI2 & 0.801 & Valid & & & \\
\hline$P I 3$ & 0.843 & Valid & & & \\
\hline$P I 1$ & 0.808 & Valid & & & \\
\hline $\begin{array}{c}\text { Personal } \\
\text { innovativeness }\end{array}$ & & & 0.979 & 0.765 & Reliable \\
\hline
\end{tabular}

The test results show that the instruments used all have good and reliable validity. The next step is to analyze the structural model. The results of structural model analysis show good results because they have good goodness of fit values. Table 2 describes the index of the goodness of fit of the research model.

Table 2. Value of Goodness of Fit index

\begin{tabular}{|c|c|c|c|c|}
\hline $\begin{array}{c}\text { Type goodness } \\
\text { of fit index }\end{array}$ & Indeks goodness of fit model & $\begin{array}{c}\text { Recommended } \\
\text { value }\end{array}$ & Results & Informations \\
\hline & Chi-Square Statistic or CMIN & Small & 243.3 & Good \\
Absolute fit & P & $\geq 0,05$ & 0.072 & Good \\
measures & GFI & $\leq 0,90$ & 0.908 & Good \\
& RMSEA & $\geq 0,08$ & 0.066 & Good \\
\hline $\begin{array}{c}\text { Incremental fit } \\
\text { measures }\end{array}$ & TLI & $\geq 0,94$ & 0.914 & \multirow{2}{*}{ Good } \\
\hline $\begin{array}{c}\text { Parsimonious fit } \\
\text { measures }\end{array}$ & Normed $\chi^{2}(\mathrm{CMIN} / \mathrm{DF})$ & $1 \leq$ Normed $\chi^{2} \leq 5$ & 1.978 & \multirow{2}{*}{ Good } \\
\hline
\end{tabular}

Table 3. Value of Goodness of Fit index

\begin{tabular}{|c|c|c|c|c|}
\hline $\begin{array}{c}\text { Type goodness } \\
\text { offit index }\end{array}$ & Indeks goodness of fit model & $\begin{array}{c}\text { Recommended } \\
\text { value }\end{array}$ & Results & Informations \\
\hline & Chi-Square Statistic or CMIN & Small & 243.3 & Good \\
Absolute fit & P & $\geq 0,05$ & 0.072 & Good \\
measures & GFI & $\geq 0,90$ & 0.908 & Good \\
& RMSEA & $\geq 0,08$ & 0.066 & Good \\
\hline $\begin{array}{c}\text { Incremental fit } \\
\text { measures }\end{array}$ & TLI & $\geq 0,90$ & 0.914 & Good \\
\hline $\begin{array}{c}\text { Parsimonious fit } \\
\text { measures }\end{array}$ & Normed $\chi^{2}(\mathrm{CMIN} / \mathrm{DF})$ & $1 \leq$ Normed $\chi^{2} \leq 5$ & 1.978 & \multirow{2}{*}{ Good } \\
\hline
\end{tabular}




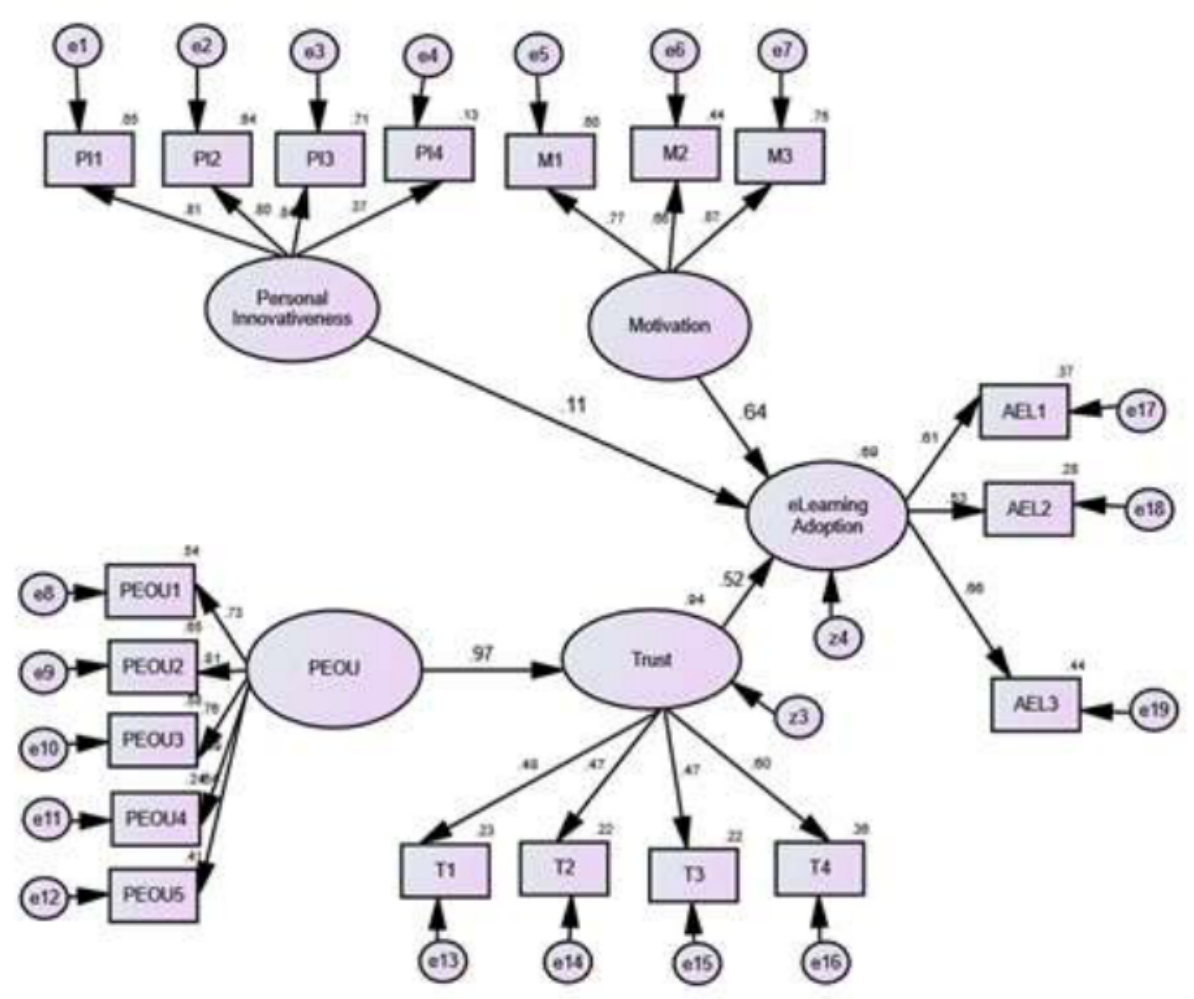

Figure 1: Model structural adopsi e-learning

Figure 1 shows the structural model of e-learning adoption obtained based on data analysis using structural equation modeling. The results of this study indicate that, the elearning adoption model developed is acceptable. Technology adoption is significantly influenced by trusts by $52 \%$, influenced directly by motivation by $64 \%$. Personal innativeness cannot influence e-learning adoption because the $p$ value is $0.114(\geq 0.05)$. The effect of PEOU on trust is $97 \%$.

The results of this study indicate that the e-learning adoption model is acceptable, but there is one insignificant path, namely the innovativeness pathway to e-learning adoption. So hypothesis 4 is not supported. The results of this study do not support Nov, Ye (2008); Lu et al., (2005), and Rogers et al., (2005) which show that innovativeness plays an important role in the use of new technology (Yi et al., 2006). The effect of personal innovativeness on elearning adoption is not significant because (1) the adoption of e-learning carried out in higher education is largely a mandatory and superior decision, so personal innovativeness does not influence adoption decisions (Abrahams, 2010). (2) All personalities who have slow adoption or who are fast adopting are expected to be able to adopt this e-learning even though there are often obstacles that fail to adopt this e-learning. (3) Citrin, et al., 2000 shows that other problems in measuring innovativeness are related to time. Here there is a temporal component related to innovativeness traits. Usually the tradition of getting information about diffusion time is afterwards. To get the right information about time related to measuring innovativeness, research must capture external information and the innovation environment that precisely determines when innovativeness is considered to be the fastest and the longest.

The effect of motivation on e-learning adoption is positive, this indicates that $\mathrm{H} 1$ is accepted. This study supports the expectancy theory of Vroom (1964), which states that motivation can influence e-Learning adoption. Chen et al., (2012), also stated that the adoption of e-Learning technology tended to be more successful when a person's motivation 
to adopt was relatively high. Motivation can direct efforts to adopt technology. User preferences and motivation must be seriously considered when technology is implemented (DeSanctis, 1983). The effect of PEOU on trust is positive. This shows that H2 is accepted, meaning that someone who perceives that e-learning technology is easy to use will increasingly trust e-leaning technology. The relatively high influence of PEOU on trust shows that trust in e-learning is indeed strongly influenced by PEOU. In this study PEOU is very dominant in influencing trust, meaning that the easier e-learning technology is perceived by users, the higher the level of trust in e learning. This study supports the Technology Acceptance Model (Davis, 1989) which states that PEOU has a major influence on technology acceptance behavior. Sugandini et al., (2018a) also shows that PEOU influences individual attitudes and trust in the use of technology. Lee et al., (2013) and Chinomona (2013) stated that PEOU is a predictor or antecedent of trust (emotional and social aspects). Johnson et al., (2010) also prove that there is a link between ease of use, trust and adoption of new technologies.

The effect of trust on e-learning adoption is positive. This shows that H3 is accepted, meaning that the teaching staff believes in e-learning to make the teaching and learning process effective, so the level of e-learning adoption also increases. The results of this study support Discroll (1978); Weber and Hsee (1998) and Joseph (2005) which state that trust influences the adoption of new innovations. Chinomona (2013) states that trust is an antecedent variable in predicting technology adoption. Gefen \& Straub, (2004) also stated that trust serves as the hope of users to adopt technology. Au \& Kauffman, (2008); Schierz et al., (2010) and Sugandini et al., (2018b) state that the more users trust technology, the more users use it.

\section{CONCLUSION}

This study uses antecedents of motivation, personal innovativeness and truss in predicting elearning adoption. Wang, Dacko and Gad (2008) states that the adoption of new technology is influenced not only by personal innovativeness, but also by prior knowledge, benefit, cost and perceived newness. Reid (2015) also shows that e-learning technology adoption can also be influenced by perceived organizational support, role ambiguity, leader-member exchange and organizational commitment. Alone (2017) also stated that to predict e-learning technology adoption, it is better to use the TRA basis from Ajen and Fishbein (1980) and Technology acceptance models from Davis (1989). Sugandini et al., (2018a) also states that e-learning adoption can be influenced by autonomy, consumer novelty seeking and perceived behavioral control.

This research cannot produce a significant relationship between personal innovativeness and e-learning adoption. The effect of personal innovativeness on innovation adoption in this study is not supported, according to Sugandini et al., (2016) and Citrin, et al., (2000), one way to overcome the problem of measurement innovation, first is to distinguish innovation into two types: innate innovativeness and actualized innovativeness. Innate innovativeness is the highest level associated with someone's openness to try new experiences. Actualized innovativeness is the observation of measurable components related to specific products. For further research in analyzing the antecedents of e-learning adoption in higher education institutions, it is better to re-confirm the effect of personal innovativeness, so that it can be used to generalize the findings of this research. 


\section{REFERENCES}

[1] Abrahams, D, "Technology Adoption in Higher Education: A Framework for Identifying and Prioritising Issues and Barriers to Adoption of Instructional Technology". Journal of Applied Research in Higher Education. Volume 2. Number 2, 2010, pp. 33-49.

[2] Alone, K, "Adoption of E-Learning Technologies in Education Institutions/Organizations: A Literature Review". Asian Journal of Educational Research Research. Vol. 5 , No. 4 , 2017, pp. 63-71

[3] Au, Y. A., and Kauffman, R. J, "The economics of mobile payments: Understanding stakeholder issues for an emerging financial technology application". Electronic Commerce Research and Applications, 7, 2008, pp 141-164.

[4] Campbell, R., Pound, P., Pope, C., Britten, N., Pill R., Morgan M., and Donovan, J, "Evaluating meta-ethnography: a synthesis of qualitative research on lay experiences of diabetes and diabetes care”. Social Science \& Medicine. Vol. 56, 2003, Pp. 671-684.

[5] Chen, Yining., Harold T. Little Jr., Mark T., Ross and Qin Zhao, "Development-andevaluation-of-a-Web-2.0-annotation-system-as-a-learning-tool-in-an-e-learning environment". Computers \& Education 58 (2012) 1094-1105

[6] Chinomona, R., \& Pretorius, M, "SME manufacturers' cooperation and dependence on major dealers' expert power in distribution channels". South African Journal of Economics and Management Sciences. Vol. 12 (2), 2011, pp 170-186.

[7] Citrin, A.V., Sprott, D.E., Silverman, S.N. and Stem, D.E, "Adoption of Internet Shopping: The Role of Consumer Innovativeness." Industrial Management and Data Systems, Vol. 100, No. 7, 2000,, pp 294-300.

[8] Davis, F. D., Bagozzi, R. P., \& Warshaw, P. R, "User acceptance of computer technology: A comparison of two theoretical models". Management science, 35(8), 1989, pp 9821003. http://dx.doi.org/10.1287/mnsc.35.8.982.

[9] Davis, F.D, "Perceived Usefulness, Perceived Ease of Use, and User Acceptance of Information Technology". Management of Information Science Quarterly. Vol. 13 (3), 1989, pp 319-340.

[10] DeSanctis, G, “A Telecommuting Primer”. Datamation. Vol. 29, 1983, pp 214-220.

[11] Driscoll, J. A, "Trust and Participation in Organizational Decision-Making as Predictors of Satisfaction. Academy of Management Journal". Vol, 21, 1978, pp 44-56.

[12] Fishbein, M., \& Ajzen, I, Belief, Attitude, Intention, and Behavior: An Introduction to Theory and Research. Reading, Mass.: Addison-Wesley, 1975

[13] Gefen, D., \& Straub, D.W, "Consumer trust in B2C e-commerce and the importance of social presence: Experiments in e-products and e-services". Omega, 32 (6), 2004, 407424.

[14] Hair, Jr., Anderson, R.E., Tatham, R.L., and Black, W.C, Multivariate Data Analysis, New Jersey: Prentice-Hall International, Inc, 1998

[15] https://www.liputan6.com/tekno/read/3226423/e-learning-makin-menarik-perhatian-di2018.

[16] Johnson, L. F., Levine, A., Smith, R. S., \& Stone, S, Horizon report. Austin, TX: The New Media Consortium. Http://www.nmc.org/pdf/2010-Horizon-Report. pdf, 2010

[17] Joseph, R.C, "An Examination of Non Adoption and Decision Inertia: A Web Based Perspective," Doctoral Dissertation, The City University of NewYork, 2005 
[18] Lee, Y.-H., Hsieh, Y.-C., \& Chen, Y.-H, "An investigation of employees' use of elearning systems: Applying the technology acceptance model". Behaviour \& Information Technology. 32(2), 2013, pp 173-189. Http://dx.doi.org/10.1080/0144929X.2011.577190

[19] Lekopanye, C.M., and Mogwe, A, "Information Communication Technology Adoption in higher education sector of Botswana: a case study of Botho University". IJACSA, 5(8), 2014

[20] Lu, Yao, Yu, "Personal Innovativeness, Social Influences and Adoption of Wireless Internet Services via Mobile Technology". Journal of Strategic Information Systems, Vol.14, 2005, pp.245-268.

[21] Lu, Yu, Liu, Yao, "Technology Acceptance Model for Wireless Internet". Internet Research. Vol.13, No.3, 2003, pp, 206-222.

[22] Markus, M. L, "Toward a critical mass theory of interactive media: Universal access, interdependence and diffusion". Communications Research, 14(5), 1987, pp 491-511.

[23] Midgley, D.F, Innovation and New Product Marketing. New York: Halsied Press, John, 1977

[24] Midgley, D.F., \& Dowling, G.R, Innovativeness: The concept and its measurement. Journal of Consumer Research, 4(4), 1978, pp 229-242. doi: 10.1086/208701

[25] Midgley, D.F., \& Dowling, G.R, Innovativeness: The concept and its measurement, 1978

[26] Midgley, D.F., \& Dowling, G.R, Innovativeness: The concept and its measurement, 1978

[27] Nov, Ye, "Personality and Technology Acceptance: Personal Innovativeness in IT, Openness and Resistance to Change, Hawaii". International Conference on System Sciences, proceedings of the 41st Annual Conference, 7-10 Jan 2008, pp.448, ISSN: 15301605.

[28] Pacansky-Brock, M, Straddling the chasm: Rethinking faculty support, 2015, Retrieved from http://www.teachingwithoutwalls.com/2015/09/straddling-chasm-rethinkingfaculty.html

[29] Reid, P, "Categories for barriers to adoption of instructional technologies". Education and Information Technologies. Vol. 19, 2014, pp 383-407. doi:10.1007/s10639-012-9222-z

[30] Rogers E. M, Shoemaker and Floyd F, Communication of Innovations. New York: The Free Press, 1971

[31] Rogers, E. M, Diffusion of innovations (5th ed.). New York: The Free Press, 2003

[32] Rogers, E. M., Medina, U. E., Rivera, M. A., \& Wiley, C. J, "Complex adaptive systems and the diffusion of innovations". The Innovation Journal, 10(3), 2005, Article 29.

[33] Sabelli, N. H., \& Harris, C. J, "The role of innovation in scaling up educational innovations. In C.K. Looi\& L. W. Teh (Eds.)". Scaling educational innovations, Singapore: Springer, 2015, pp. 13-30

[34] Sahin, I., \& Thompson, A, "Using Rogers's theory to interpret instructional computer use by COE faculty". Journal of Research on Technology in Education. Vol. 39 (1), 2006, pp 81-104.

[35] Schierz, P.G., Schilke, O., \& Wirtz, B.W, Understanding consumer acceptance of mobile payment services: An empirical analysis, Electronic Commerce Research and Applications, 9 (3), 2010, pp 209-216

[36] Sekaran, U, Research Methods for Business: A Skill Building Approach (4 thedition). New Jersey: John Wiley and Sons, 2003 
[37] Selander, S, "Designs for learning and the formation and transformation of knowledge in an era of globalization". Studies in Philosophy and Education. Springer. Vol. 27, No. 4, July, 2008, pp 267-283.

[38] Selwyn, N, "Digital technologies in universities: Problems posing as solutions?" Learning, Media and Technology, 38(1), 2013, pp 1-3.

[39] Sugandini, D., Effendi, M.I., and Istanto, Y, “Adopsi dan Inovasi”. Edisi 1. Kanisius Yogyakarta, 2016

[40] Sugandini D., Purwoko., Pambudi, A., Resmi, S., Reniati., Muafi., and Kusumawati, R.A, "The Role of Uncertainty, Perceived Easy of Use, and Perceived Usefulness Towards the Technology Adoption", International Journal of Civil Engineering and Technology, Vol 9, Issue 4, 2018, p. 660-669.

[41] Sugandini, D; Feriyanto, N; Muafi; Hadioetomo and Darpito, S.H, "The Influence of Novelty Seeking Behavior and Autonomy Toward New Product Trial in The Context of E-Business Learning: The Role of Mediation Of Perceived Behavioral Control", Journal of Entrepreneurship Education. Vol. 21, Issue 3, 2018, pp: 1-9.

[42] Vroom V.H, Work and Motivation, Willey: New York, 1964

[43] Wang, Qing. Scott Dacko., and Gad, Marwa, "Factors Influencing Consumers' Evaluation and Adoption Intention of Really-New Products Or Services: Prior Knowledge, Innovativeness and Timing of Product Evaluation in NA". Advances in Consumer Research eds. Angela Y. Lee and DilipSoman, Duluth, MN: Association for Consumer Research Vol. 35, 2008, Pages: 416-422.

[44] Weber, E.U and Hsee, C, "Cross-Cultural Differences in Risk Perception, but CrossCultural Similarities in Attitude towards Perceived Risk," Management Science, Vol. 44 No.9, 1998, pp 1205-1217.

[45] Yi, Jackson., and Park, P, "Understanding Information Technology Acceptance by Individual Proffesionals: Toward an Integrative View". Information and Management. Vol.43, 2006, pp.350-363. 